OPEN ACCESS

Edited by:

Wuping Sun,

Shenzhen University, China

Reviewed by:

Toshiaki Makino,

Nagoya City University, Japan Yasuhito Uezono,

Jikei University School of Medicine,

Japan

${ }^{*}$ Correspondence:

Masataka Sunagawa

suna@med.showa-u.ac.jp

Specialty section:

This article was submitted to Pain Mechanisms and Modulators,

a section of the journal

Frontiers in Molecular Neuroscience

Received: 04 May 2021

Accepted: 22 November 2021

Published: 14 December 2021

Citation:

Sunagawa M, Takayama Y,

Kato M, Tanaka M, Fukuoka S,

Okumo T, Tsukada $M$ and

Yamaguchi K (2021) Kampo Formulae

for the Treatment of Neuropathic Pain

$\sim$ Especially the Mechanism of Action

of Yokukansan .

Front. Mol. Neurosci. 14:705023.

doi: 10.3389/fnmol.2021.705023

\section{Kampo Formulae for the Treatment of Neuropathic Pain Especially the Mechanism of Action of Yokukansan}

\author{
Masataka Sunagawa ${ }^{1 *}$, Yasunori Takayama ${ }^{1}$, Mami Kato $^{1}$, Midori Tanaka ${ }^{1,2}$, \\ Seiya Fukuoka',3, Takayuki Okumo', Mana Tsukada' ${ }^{1}$ and Kojiro Yamaguchi' \\ ${ }^{1}$ Department of Physiology, School of Medicine, Showa University, Tokyo, Japan, ${ }^{2}$ Department of Rehabilitation Medicine, \\ School of Medicine, Showa University, Tokyo, Japan, ${ }^{3}$ Department of Ophthalmology, School of Medicine, Showa University, \\ Tokyo, Japan
}

Kampo medicine has been practiced as traditional medicine (TM) in Japan. Kampo medicine uses Kampo formulae that are composed of multiple crude drugs to make Kampo formulae. In Japan, Kampo formulae are commonly used instead of or combined with Western medicines. If drug therapy that follows the guidelines for neuropathic pain does not work or cannot be taken due to side effects, various Kampo formulae are considered as the next line of treatment. Since Kampo formulae are composed of two or more kinds of natural crude drugs, and their extracts contain many ingredients with pharmacological effects, one Kampo formula usually has multiple effects. Therefore, when selecting a formula, we consider symptoms other than pain. This review outlines the Kampo formulae that are frequently used for pain treatment and their crude drugs and the basic usage of each component. In recent years, Yokukansan (YKS) has become one of the most used Kampo formulae for pain treatment with an increasing body of baseline research available. We outline the known and possible mechanisms by which YKS exerts its pharmacologic benefits as an example of Kampo formulae's potency and holistic healing properties.

Keywords: neuropathic pain, analgesic effect, Kampo formula, Kampo medicine, Yokukansan

\section{INTRODUCTION}

Tricyclic antidepressants, calcium channel $\alpha 2 \delta$ ligands such as gabapentin and pregabalin, and serotonin noradrenaline reuptake inhibitors (SNRIs) are the first choices for treating neuropathic pain according to the Japan Pain Clinic Society's guidelines for drug therapy (Sumitani et al., 2018). An extract from inflammatory rabbit skin inoculated with vaccinia virus, Neurotropin, and tramadol are second-line treatments. The third-line treatment is potent opioids, such as morphine, fentanyl, and oxycodone. Carbamazepine is the first choice for trigeminal neuralgia,

Abbreviations: SNRI, serotonin noradrenaline reuptake inhibitor; GJG, Goshajinkigan; EJT, Eppikajutsuto; KBG, Keishibukuryogan; GRS, Goreisan; YKS, Yokukansan; JTT, Juzentaihoto; KJT, Keishikajutsubuto; SKT, Saikokeishito; CRPS, complex regional pain syndrome; CCI, chronic constriction injury; PSL, partial sciatic nerve ligation; NMDA, $N$-methyl-Daspartate. 
while lamotrigine and baclofen are the second choices. However, the actual efficacy rates of these drugs are low (Finnerup et al., 2015). In many cases, patients have been unable to take them due to side effects. In such cases, Kampo formulae are used as a treatment option in Japan. The Japanese Ministry of Health, Labor, and Welfare has officially approved the clinical use of Kampo formulae as an ethical pharmaceutical. Kampo medicine has been practiced as traditional medicine (TM) in Japan. Kampo medicine uses Kampo formulae that are composed of multiple crude drugs to make Kampo formulae. In recent years, the need for Kampo medicine has increased, and more than $80 \%$ of doctors prescribe Kampo formulae clinically (Ito et al., 2012; Moschik et al., 2012). We herein review examples of the clinical uses of Kampo formulae for neuropathic pain and their action mechanisms based on findings in the literature.

\section{KAMPO FORMULAE FOR NEUROPATHIC PAIN}

Kampo formulae are composed of two or more kinds of natural crude drugs, and the decoctions of their mixtures are generally administered. One of the characteristics of Kampo formulae is that they are multi-component formulations, unlike most Western medicines. A single medicine has an analgesic effect along with various other effects such as improving blood flow and coldness while reducing swelling and stress. Therefore, when selecting a Kampo formula, we check for symptoms other than pain.

Table 1 shows examples. For example, patients whose pain is exacerbated by cold stimulation require medicine that relieves pain and simultaneously warms the body. Patients with an impaired blood flow receive medicine that improves the blood flow while reducing pain. Since the factors that make the pain worse can also be improved simultaneously, the therapeutic effect is higher than the administration of analgesics alone. The second feature is that almost no side effects are developed. Kampo medicines have a long history (Kuchta, 2019), and in the process, ineffective and poisonous components have been naturally eliminated. At present, only potent and safe Kampo formulae are cataloged.

Table 2 lists the Kampo formulae frequently used to treat chronic pain, their crude drugs, and each crude drug's main actions and components, classified according to their effects based on Kampo medicine. (TM) has been added to certain terms to indicate that their meaning in this content is in relation to traditional Kampo medicine. Crude drugs with mainly analgesic and anti-inflammatory effects are assigned to Class 1, those with anti-stress effects are assigned to Class 2, and those that improve blood (TM) disturbances are assigned to Class 3. Blood (TM) is a red fluid that supports the nutrition and metabolism of the body, and its disturbance patterns include static blood (TM) and blood (TM) deficiency (The Editing Committee for the Dictionary of Kampo Medicine, the Japan Society for Oriental Medicine, 2020). In addition, crude drugs that enhance the digestive function and improve physical strength are assigned to Class 4 , whereas those that improve water metabolism, suppress swelling, and confer a diuretic effect are assigned to Class 5 . Class 4 includes crude drugs that have a qi (TM)-tonifying effect. Qi is a fundamental energy required for life activities. Class 5 includes drugs that have a fluid (TM)-regulating effect. Fluid is a colorless fluid that supports nutrition and metabolism including interstitial fluid and lymph. Weights (g) indicate the amount of each crude drug used to produce each Kampo formula, and the drugs marked with $\left(^{*}\right)$ are those that play the most central role in each Kampo formula (Takayama, 2019). Aside from Goshajinkigan (GJG) and Yokukansan (YKS), the contents of crude drugs differ depending on the manufacturers, so some patterns were shown. These doses of crude drugs are mixed, and the decoction is administered.

\section{Goshajinkigan (Chinese Name: Niu Che Sen Qi Wan)}

Goshajinkigan was first described in Ji Sheng Fang published in 1253 in China (Yan and Liu, 2012). It is a well-balanced combination of Class 3-5 crude drugs plus Aconiti radix processa and Cinnamomi cortex, which have strong analgesic and warming effects. This combination is suitable for patients who have a decreased physical function, are extremely tired, and complain of coldness, especially in the lower limbs, a dry mouth, and dysuria. GJG is often prescribed for inferior limb pain and lower back pain (Hamaguchi et al., 2017). Recent reports have suggested that GJG may prevent chemotherapy-induced peripheral neuropathy (Nishioka et al., 2011; Cascella and Muzio, 2017).

\section{Eppikajutsuto (Yue Bi Jia Zhu Tang)}

Eppikajutsuto (EJT) was first described in Jin Gui Yao Lue published around $200 \mathrm{AD}$ in China (Zhang, 2020). EJT mainly includes Class 1 crude drugs, such as Ephedrae Herba, Gypsum fibrosum, and Glycyrrhizae radix, which have antiinflammatory activities, and Atractylodis lanceae rhizoma, which improves an uneven distribution of water, such as in case of edema. EJT is useful for relieving edema and knee effusion caused by allergies and inflammation, especially rheumatoid arthritis (Kogure et al., 2013). Since EJT has a very strong anti-inflammatory effect, it is an alternative to non-steroidal anti-inflammatory drugs in patients with gastrointestinal disorders.

\section{Keishibukuryogan (Gui Zhi Fu Ling Wan)}

Keishibukuryogan (KBG), which was first described in Jin Gui Yao Lue (Zhang, 2020), is a Kampo formula that improves various symptoms caused by a decreased blood flow and stagnation (Nozaki et al., 2007; Tomita et al., 2017). It is composed of Persicae semen and Moutan cortex, which belong to Class 3, and Paeoniae radix, which improves the blood flow. In addition, the analgesic and anti-inflammatory effects of Paeoniae radix and Cinnamomi cortex, which belong to Class 1 , are also present. The administration of KBG is reported to warm diseased limbs and improve post-stroke cold sensations and numbness in the affected body parts by increasing the peripheral blood flow (Fujita et al., 2010). 
TABLE 1 | Treatment strategies and examples of drug selection in Kampo medicine.

\begin{tabular}{|c|c|c|c|}
\hline $\begin{array}{l}\text { Characteristic symptoms other } \\
\text { than pain }\end{array}$ & Treatment strategies & $\begin{array}{l}\text { Representative example } \\
\text { of Kampo formulae }\end{array}$ & References \\
\hline Cold & Warm & Goshajinkigan (GJG) & Takayama et al., 2018; Matsubara et al., 2021 \\
\hline Heat/inflammation & Cool/anti-inflammatory & Eppikajutsuto (EJT) & Kogure et al., 2013; Shinkai et al., 2017 \\
\hline Microangiopathy & Improving blood flow & Keishibukuryogan (KBG) & Endo et al., 2008; Fujita et al., 2010 \\
\hline Dropsy/abnormal water metabolism & Improving water metabolism & Goreisan (GRS) & Yano et al., 2017; Murakami et al., 2021 \\
\hline Stress/anxiety & Antistress/antianxiety & Yokukansan (YKS) & Katahira et al., 2017; Wada et al., 2017 \\
\hline $\begin{array}{l}\text { Decreased physical } \\
\text { strength/immune deficiency }\end{array}$ & $\begin{array}{l}\text { Improving physical } \\
\text { fitness/improving immunity }\end{array}$ & Juzentaihoto (JTT) & Ishikawa et al., 2017; Takaku et al., 2020 \\
\hline
\end{tabular}

\section{Goreisan (Wu Ling San)}

Goreisan (GRS) was first described in Jin Gui Yao Lue (Zhang, 2020) and Shang Hang Lun published around $200 \mathrm{AD}$ in China (Zhang, 1999). GRS consists of Atractylodis lanceae rhizoma (or Atractylodis rhizoma), Alismatis tuber, Poria, and Polyporus (Class 5), which relieve water retention in such conditions as edema, oliguria, and diarrhea and Cinnamomi cortex, which has analgesic, anti-inflammatory, and warming effects. GRS is administered to patients with exacerbated pain due to swelling. Changes in barometric pressure that accompany weather changes can exacerbate pain, and GRS is effective in such cases (Kurihara et al., 2018).

\section{Yokukansan (Yi Gan San)}

YKS was first described in a Chinese medical book Bao Ying Cuo Yao published in 1556 (Kai and Ji, 2016). One characteristic of YKS is that it is mainly composed of Bupleuri radix and Uncariae uncis cum ramulus (Class 2), which have anti-stress effects. In addition, it contains crude drugs from Classes 3 to 5 . It is useful for patients with a weak constitution, especially those with frustration and anger due to increased sensitivity to stress. Originally, YKS was administered to patients with symptoms of emotional irritability, neurosis, and insomnia and to infants suffering from night crying and convulsions (de Caires and Steenkamp, 2010). The crude drug components of YKS, including Glycyrrhizae radix, Bupleuri radix, Uncariae uncis cum ramulus, and Cnidii rhizome, have analgesic effects. Thus, YKS is also used to treat various pain disorders, including fibromyalgia, postherpetic neuralgia, phantom-limb pain, headache, and trigeminal neuralgia (Nakamura et al., 2009; Yamaguchi, 2015; Sugasawa, 2016; Akiyama and Hasegawa, 2019). Many studies have been published concerning the mechanism of analgesic action of YKS. Chronic pain causes stress, and stress further promotes and exacerbates pain (Hannibal and Bishop, 2014). YKS is effective in such cases.

\section{Juzentaihoto (Shi Quan Da Bu Tang)}

Juzentaihoto (JTT) was first described in Taiping Huimin Heji Ju Fang published (1151) in China (Ping et al., 2017). Longlasting pain deprives patients of physical strength and reduces their willingness to fight illness. Chronic pain may alter immune response, which can affect recovery from chronic pain (Herzberg et al., 1994; Sunagawa et al., 2000; Bethea and Fischer, 2021). The main components of JTT, Ginseng radix, and Astragali radix
(Class 4) improve fatigue, malaise, loss of appetite, and weakened immunity. JTT should improve physical strength to fight illness (Yamakawa et al., 2016). In addition, JTT contains crude drugs from Classes 3 to 5. Glycyrrhizae radix, Paeoniae radix, and Cinnamomi cortex, which have analgesic effects, contribute to a well-balanced formula. JTT is frequently used for cancer patients because it enhances immune function (Saiki et al., 2017; OgawaOchiai et al., 2021).

\section{Keishikajutsubuto (Gui Zhi Jia Zhu Fu Tang)}

Keishikajutsubuto (KJT) was produced by Japanese doctor Todo Yoshimasu (1702-1773) and described in Hoki (Yoshimasu, 1181). KJT is mainly composed of Class 1 drugs with antiinflammatory and analgesic effects. In addition to its strong analgesic effect, Aconiti radix processa, Atractylodis lanceae rhizoma (Class 5), Cinnamomi cortex (Class 1), and Zingiberis rhizoma (Class 4) variously offer warming and diuretic effects. $\mathrm{KJT}$ is effective for joint pain and neuralgia associated with coldness and swelling (Nakanishi et al., 2012). Although the crude constituent drugs are similar to EJT, EJT contains Gypsum fibrosum and Ephedrae Herba, which have strong antiinflammatory effects, and treats cases without coldness.

\section{KAMPO FORMULAE FOR TRIGEMINAL AND GLOSSOPHARYNGEAL NEURALGIAS}

In Western medicine, treatment strategies differ between trigeminal neuralgia and neuralgia in other parts of the body. Similarly, the drugs used in Kampo medicine are slightly different. Trigeminal neuralgia is divided into idiopathic trigeminal neuralgia caused by the compression of blood vessels around the nerve and symptomatic trigeminal neuralgia caused by organic diseases, such as tumors, other than vascular compression. Drug treatment is less invasive than surgery and is often the first treatment choice, including to achieve pain relief before surgery. In addition, drug administration is performed when surgical therapy, radiation therapy, and nerve block cannot be performed, or when symptoms recur. As mentioned above, the first-line drug is carbamazepine, an antiepileptic drug, but its number needed to harm is 3.4 (Cruccu et al., 2008). Its side effects, including gastrointestinal symptoms, light-headedness, 
TABLE 2 | Kampo formulae for chronic pain and crude constituent drugs.

\begin{tabular}{|c|c|c|c|c|c|c|c|c|c|c|c|c|c|c|c|c|c|c|c|c|}
\hline \multirow[t]{3}{*}{ Classification } & \multicolumn{4}{|c|}{ Crude drugs } & \multicolumn{15}{|c|}{ Kampo formulae } & \multirow[t]{3}{*}{ References } \\
\hline & \multirow{2}{*}{$\begin{array}{l}\text { Latin } \\
\text { name }\end{array}$} & \multirow{2}{*}{$\begin{array}{l}\text { English } \\
\text { name }\end{array}$} & \multirow[t]{2}{*}{ Main effects } & \multirow{2}{*}{$\begin{array}{l}\text { Major } \\
\text { component }\end{array}$} & \multirow[t]{2}{*}{ GJG } & \multicolumn{2}{|c|}{ EJT } & \multicolumn{2}{|c|}{ KBG } & \multicolumn{3}{|c|}{ GRS } & \multirow[t]{2}{*}{ YKS } & \multicolumn{2}{|c|}{ JTT } & \multirow[t]{2}{*}{ KJT } & \multicolumn{3}{|c|}{ SKT } & \\
\hline & & & & & & (1) & (2) & (1) & (2) & (1) & (2) & (3) & & (1) & (2) & & (1) & (2) & (3) & \\
\hline \multirow[t]{7}{*}{1} & $\begin{array}{l}\text { Aconiti } \\
\text { radix } \\
\text { processa }\end{array}$ & $\begin{array}{l}\text { Processed } \\
\text { Aconiti root }\end{array}$ & $\begin{array}{l}\text { Analgesia, } \\
\text { cardiotonic, warm }\end{array}$ & Aconitine & 1.0 & & & & & & & & & & & 0.5 or 1.0 & & & & $\begin{array}{l}\text { Yu et al., 2012; Deng } \\
\text { et al., 2021; Qiu et al., } \\
\text { 2021. }\end{array}$ \\
\hline & $\begin{array}{l}\text { Glycyrrhizae } \\
\text { radix }\end{array}$ & Glycyrrhiza & $\begin{array}{l}\text { Analgesia, } \\
\text { antiinflammation, } \\
\text { antitussive }\end{array}$ & Glycyrrhizin & & 2.0 & 2.0 & & & & & & 1.5 & 1.0 & 1.5 & 2.0 & 1.5 & 1.5 & 2.0 & $\begin{array}{l}\text { Kamei et al., 2005; } \\
\text { Wang et al., } 2015\end{array}$ \\
\hline & $\begin{array}{l}\text { Paeoniae } \\
\text { radix }\end{array}$ & Peony root & $\begin{array}{l}\text { Analgesia, } \\
\text { antiinflammation, } \\
\text { improving static } \\
\text { blood (TM), } \\
\text { sedation }\end{array}$ & Paeoniflorin & & & & 3.0 & 4.0 & & & & & 3.0 & 3.0 & 4.0 & 2.0 & 2.5 & 2.0 & $\begin{array}{l}\text { Li et al., 2014; Yin et al., } \\
\text { 2016; Xin et al., } 2019 .\end{array}$ \\
\hline & $\begin{array}{l}\text { Cinnamomi } \\
\text { cortex }\end{array}$ & $\begin{array}{l}\text { Cinnamon } \\
\text { bark }\end{array}$ & $\begin{array}{l}\text { Analgesia, } \\
\text { antiinflammation, } \\
\text { perspiration, warm }\end{array}$ & Cinnamaldehyde & 1.0 & & & 3.0 & 4.0 & 3.0 & 2.0 & 1.5 & & 3.0 & 3.0 & $4.0^{*}$ & 2.5 & 2.5 & 2.0 & $\begin{array}{l}\text { Iwasaki et al., 2008; } \\
\text { Churihar et al., 2016; } \\
\text { Lee et al., } 2018 .\end{array}$ \\
\hline & $\begin{array}{l}\text { Gypsum } \\
\text { fibrosum }\end{array}$ & Gypsum & $\begin{array}{l}\text { Antiinflammation, } \\
\text { sedation }\end{array}$ & Calcium sulfate & & 8.0 & 8.0 & & & & & & & & & & & & & Liu et al., 2021. \\
\hline & $\begin{array}{l}\text { Ephedrae } \\
\text { Herba }\end{array}$ & $\begin{array}{l}\text { Ephedrae } \\
\text { Herb }\end{array}$ & $\begin{array}{l}\text { Antiinflammation, } \\
\text { perspiration, } \\
\text { antitussive }\end{array}$ & Ephedrine & & $6.0^{*}$ & $6.0^{\star}$ & & & & & & & & & & & & & $\begin{array}{l}\text { Miyagoshi et al., 1986; } \\
\text { Wu et al., 2014; Cheng } \\
\text { et al., } 2017 .\end{array}$ \\
\hline & $\begin{array}{l}\text { Scutellariae } \\
\text { radix }\end{array}$ & $\begin{array}{l}\text { Scutellaria } \\
\text { root }\end{array}$ & Antiinflammation & Baicalin & & & & & & & & & & & & & 2.0 & 2.0 & 2.0 & Shimizu et al., 2018. \\
\hline \multirow[t]{3}{*}{2} & $\begin{array}{l}\text { Pinelliae } \\
\text { tuber }\end{array}$ & $\begin{array}{l}\text { Pinellia } \\
\text { tuber }\end{array}$ & $\begin{array}{l}\text { Antistress, } \\
\text { sedation, } \\
\text { antitussive }\end{array}$ & $\begin{array}{l}\text { Homogentisic } \\
\text { acid }\end{array}$ & & & & & & & & & & & & & 4.0 & 4.0 & 4.0 & $\begin{array}{l}\text { Goto et al., 2013; Lin } \\
\text { et al., } 2019 .\end{array}$ \\
\hline & $\begin{array}{l}\text { Bupleuri } \\
\text { radix }\end{array}$ & $\begin{array}{l}\text { Bupleurum } \\
\text { root }\end{array}$ & $\begin{array}{l}\text { Antistress, } \\
\text { antiinflammation, } \\
\text { analgesia }\end{array}$ & Saikosaponin & & & & & & & & & 2.0 & & & & $5.0^{*}$ & $5.0^{*}$ & $5.0^{*}$ & $\begin{array}{l}\text { Shin et al., 2019; Guo } \\
\text { et al., 2020; Xu et al., } \\
\text { 2021. }\end{array}$ \\
\hline & $\begin{array}{l}\text { Uncariae } \\
\text { uncis cum } \\
\text { ramulus }\end{array}$ & $\begin{array}{l}\text { Uncaria } \\
\text { hook }\end{array}$ & $\begin{array}{l}\text { Antistress, } \\
\text { vasodilation, } \\
\text { analgesia }\end{array}$ & Rhynchophylline & & & & & & & & & $3.0^{*}$ & & & & & & & $\begin{array}{l}\text { Pengsuparp et al., } \\
\text { 2001; Loh et al., 2017; } \\
\text { Qiao et al., 2021. }\end{array}$ \\
\hline
\end{tabular}


TABLE 2 | (Continued)

\begin{tabular}{|c|c|c|c|c|c|c|c|c|c|c|c|c|c|c|c|c|c|c|c|c|}
\hline \multirow[t]{3}{*}{ Classification } & \multicolumn{4}{|c|}{ Crude drugs } & \multicolumn{15}{|c|}{ Kampo formulae } & \multirow[t]{3}{*}{ References } \\
\hline & \multirow{2}{*}{$\begin{array}{l}\text { Latin } \\
\text { name }\end{array}$} & \multirow{2}{*}{$\begin{array}{l}\text { English } \\
\text { name }\end{array}$} & \multirow[t]{2}{*}{ Main effects } & \multirow{2}{*}{$\begin{array}{l}\text { Major } \\
\text { component }\end{array}$} & \multirow[t]{2}{*}{ GJG } & \multicolumn{2}{|c|}{ EJT } & \multicolumn{2}{|c|}{ KBG } & \multicolumn{3}{|c|}{ GRS } & \multirow[t]{2}{*}{ YKS } & \multicolumn{2}{|c|}{ JTT } & \multirow[t]{2}{*}{ KJT } & \multicolumn{3}{|c|}{ SKT } & \\
\hline & & & & & & (1) & (2) & $(1)$ & (2) & (1) & (2) & (3) & & (1) & (2) & & (1) & (2) & (3) & \\
\hline \multirow[t]{6}{*}{3} & $\begin{array}{l}\text { Persicae } \\
\text { semen }\end{array}$ & $\begin{array}{l}\text { Peach } \\
\text { kernel }\end{array}$ & $\begin{array}{l}\text { Improving static } \\
\text { blood (TM), } \\
\text { antiinflammation }\end{array}$ & Amygdalin & & & & $3.0^{\star}$ & $4.0^{*}$ & & & & & & & & & & & $\begin{array}{l}\text { Hao et al., 2019; He } \\
\text { et al., } 2020 .\end{array}$ \\
\hline & $\begin{array}{l}\text { Moutan } \\
\text { cortex }\end{array}$ & $\begin{array}{l}\text { Moutan } \\
\text { bark }\end{array}$ & $\begin{array}{l}\text { Improving static } \\
\text { blood (TM) }\end{array}$ & Paeonol & 3.0 & & & $3.0^{\star}$ & $4.0^{*}$ & & & & & & & & & & & Hirai et al., 1983. \\
\hline & $\begin{array}{l}\text { Rehmanniae } \\
\text { radix }\end{array}$ & $\begin{array}{l}\text { Rehmannia } \\
\text { root }\end{array}$ & $\begin{array}{l}\text { Tonifying blood } \\
\text { (TM), analeptic }\end{array}$ & Catalpol & $5.0^{*}$ & & & & & & & & & 3.5 & 3.0 & & & & & $\begin{array}{l}\text { Leong et al., 2018; Wu } \\
\text { et al., 2019. }\end{array}$ \\
\hline & $\begin{array}{l}\text { Angelicae } \\
\text { acutilobae } \\
\text { radix }\end{array}$ & $\begin{array}{l}\text { Japanese } \\
\text { angelica } \\
\text { root }\end{array}$ & $\begin{array}{l}\text { Tonifying blood } \\
(\mathrm{TM}) \text {, analeptic }\end{array}$ & Ligustilide & & & & & & & & & 3.0 & 3.5 & 3.0 & & & & & $\begin{array}{l}\text { Shimizu et al., 1991; } \\
\text { Hatano et al., } 2004 .\end{array}$ \\
\hline & $\begin{array}{l}\text { Achyranthis } \\
\text { radix }\end{array}$ & $\begin{array}{l}\text { Achyranthes } \\
\text { root }\end{array}$ & $\begin{array}{l}\text { Improving static } \\
\text { blood (TM), } \\
\text { improving of fluid } \\
\text { (TM), analgesia }\end{array}$ & Ecdysterone & 3.0 & & & & & & & & & & & & & & & $\begin{array}{l}\text { Luo et al., 2009; Jung } \\
\text { et al., 2015; He et al., } \\
2017 .\end{array}$ \\
\hline & $\begin{array}{l}\text { Cnidii } \\
\text { rhizoma }\end{array}$ & $\begin{array}{l}\text { Cnidium } \\
\text { rhizome }\end{array}$ & $\begin{array}{l}\text { Tonifying blood } \\
\text { (TM), analgesia, } \\
\text { analeptic }\end{array}$ & Cnidilide & & & & & & & & & 3.0 & 3.0 & 3.0 & & & & & $\begin{array}{l}\text { Choi et al., 2016; Lee } \\
\text { et al., 2016; Ningsih } \\
\text { et al., 2020. }\end{array}$ \\
\hline \multirow[t]{6}{*}{4} & $\begin{array}{l}\text { Ginseng } \\
\text { radix }\end{array}$ & Ginseng & $\begin{array}{l}\text { Tonifying qi (TM), } \\
\text { analeptic, } \\
\text { stomachic }\end{array}$ & Ginsenoside & & & & & & & & & & $2.5^{\star}$ & $3.0^{*}$ & & 2.0 & 2.0 & 2.0 & $\begin{array}{l}\text { Zhang et al., 2019; Fan } \\
\text { et al., 2021; Qu et al., } \\
\text { 2021. }\end{array}$ \\
\hline & $\begin{array}{l}\text { Corni } \\
\text { fructus }\end{array}$ & Cornus fruit & $\begin{array}{l}\text { Tonifying qi (TM), } \\
\text { analeptic }\end{array}$ & Loganin & 3.0 & & & & & & & & & & & & & & & Dong et al., 2018. \\
\hline & $\begin{array}{l}\text { Dioscoreae } \\
\text { rhizoma }\end{array}$ & $\begin{array}{l}\text { Dioscorea } \\
\text { rhizome }\end{array}$ & $\begin{array}{l}\text { Tonifying qi (TM), } \\
\text { analeptic, } \\
\text { antitussive }\end{array}$ & Diosgenin & 3.0 & & & & & & & & & & & & & & & Kim et al., 2012. \\
\hline & $\begin{array}{l}\text { Zizyphi } \\
\text { fructus }\end{array}$ & Jujube & $\begin{array}{l}\text { Tonifying qi (TM), } \\
\text { analeptic, antistress }\end{array}$ & $\begin{array}{l}\text { Zizyphus } \\
\text { saponin }\end{array}$ & & 3.0 & 3.0 & & & & & & & & & 4.0 & 2.0 & 2.0 & 2.0 & $\begin{array}{l}\text { Peng et al., 2000; } \\
\text { Irshad et al., 2020; } \\
\text { Wang et al., 2020. }\end{array}$ \\
\hline & $\begin{array}{l}\text { Zingiberis } \\
\text { rhizoma }\end{array}$ & Ginger & Stomachic, warm & Gingerol & & 1.0 & 0.8 & & & & & & & & & 1.0 & 0.5 or 1.0 & 1.0 & 2.0 & $\begin{array}{l}\text { Yoshikawa et al., 1994; } \\
\text { Chang et al., 1995; } \\
\text { Chrubasik et al., 2005. }\end{array}$ \\
\hline & $\begin{array}{l}\text { Astragali } \\
\text { radix }\end{array}$ & $\begin{array}{l}\text { Astragalus } \\
\text { root }\end{array}$ & $\begin{array}{l}\text { Tonifying qi (TM), } \\
\text { analeptic, } \\
\text { cardiotonic }\end{array}$ & Formononetin & & & & & & & & & & 2.5 & 3.0 & & & & & $\begin{array}{l}\text { Zhang et al., 2011; Wei } \\
\text { et al., } 2021 .\end{array}$ \\
\hline
\end{tabular}


TABLE 2 | (Continued)

\begin{tabular}{|c|c|c|c|c|c|c|c|c|c|c|c|c|c|c|c|c|c|c|c|}
\hline \multirow[t]{3}{*}{ Classification } & \multicolumn{4}{|c|}{ Crude drugs } & \multicolumn{14}{|c|}{ Kampo formulae } & \multirow[t]{3}{*}{ References } \\
\hline & \multirow{2}{*}{$\begin{array}{l}\text { Latin } \\
\text { name }\end{array}$} & \multirow{2}{*}{$\begin{array}{l}\text { English } \\
\text { name }\end{array}$} & \multirow[t]{2}{*}{ Main effects } & \multirow{2}{*}{$\begin{array}{l}\text { Major } \\
\text { component }\end{array}$} & \multirow[t]{2}{*}{ GJG } & \multicolumn{2}{|c|}{ EJT } & \multicolumn{2}{|c|}{ KBG } & \multicolumn{3}{|c|}{ GRS } & \multirow[t]{2}{*}{ YKS } & \multicolumn{2}{|c|}{ JTT } & \multirow[t]{2}{*}{ KJT } & \multicolumn{2}{|r|}{ SKT } & \\
\hline & & & & & & (1) & (2) & (1) & (2) & (1) & (2) & (3) & & (1) & (2) & & (1) & (2) (3) & \\
\hline \multirow[t]{6}{*}{5} & $\begin{array}{l}\text { Atractylodis } \\
\text { rhizoma }\end{array}$ & $\begin{array}{l}\text { Atractylodes } \\
\text { rhizome }\end{array}$ & $\begin{array}{l}\text { Improving static } \\
\text { blood (TM), } \\
\text { anti-edema, } \\
\text { stomachic }\end{array}$ & Atractylon & & & & & & $4.5^{\#}$ & 3.0 & & $4.0^{\#}$ & 3.5 & $3.0^{\#}$ & & & & $\begin{array}{l}\text { Hwang et al., 1996; Shi } \\
\text { et al., 2019; Zhang } \\
\text { et al., 2021. }\end{array}$ \\
\hline & $\begin{array}{l}\text { Atractylodis } \\
\text { lanceae } \\
\text { rhizoma }\end{array}$ & $\begin{array}{l}\text { Atractylodes } \\
\text { lancea } \\
\text { rhizome }\end{array}$ & $\begin{array}{l}\text { Improving of fluid } \\
\text { (TM), anti-edema, } \\
\text { stomachic, } \\
\text { perspiration }\end{array}$ & Atractylodin & & 4.0 & 4.0 & & & $4.5^{\#}$ & & 3.0 & $4.0^{\#}$ & & $3.0^{\#}$ & 4.0 & & & $\begin{array}{l}\text { Yamahara et al., 1990; } \\
\text { Koonrungsesomboon } \\
\text { et al., 2014; Yu et al., } \\
2017 .\end{array}$ \\
\hline & $\begin{array}{l}\text { Alismatis } \\
\text { tuber }\end{array}$ & $\begin{array}{l}\text { Alisma } \\
\text { tuber }\end{array}$ & $\begin{array}{l}\text { Improving of fluid } \\
(\mathrm{TM}) \text {, anti-edema }\end{array}$ & Alisol & 3.0 & & & & & 6.0 & 5.0 & 4.0 & & & & & & & $\begin{array}{l}\text { Makino et al., 2002; } \\
\text { Han et al., } 2013 .\end{array}$ \\
\hline & Poria & $\begin{array}{l}\text { Poria } \\
\text { sclerotium }\end{array}$ & $\begin{array}{l}\text { Improving of fluid } \\
\text { (TM), anti-edema, } \\
\text { stomachic, } \\
\text { antistress }\end{array}$ & Eburicoic acid & 3.0 & & & 3.0 & 4.0 & $4.5^{\star}$ & $3.0^{*}$ & $3.0^{*}$ & 4.0 & 3.5 & 3.0 & & & & $\begin{array}{l}\text { Nukaya et al., 1996; } \\
\text { Lee et al., 2012; Lu } \\
\text { et al., 2021. }\end{array}$ \\
\hline & Polyporus & $\begin{array}{l}\text { Polyporus } \\
\text { sclerotium }\end{array}$ & $\begin{array}{l}\text { Improving of fluid } \\
\text { (TM), anti-edema, } \\
\text { antiinflammation }\end{array}$ & Ergosterol & & & & & & 4.5 & 3.0 & 3.0 & & & & & & & $\begin{array}{l}\text { Sun and Yasukawa, } \\
\text { 2008; Zhang et al., } \\
2010 .\end{array}$ \\
\hline & $\begin{array}{l}\text { Plantaginis } \\
\text { semen }\end{array}$ & $\begin{array}{l}\text { Plantago } \\
\text { seed }\end{array}$ & $\begin{array}{l}\text { Improving of fluid } \\
\text { (TM), anti-edema, } \\
\text { antiinflammation, } \\
\text { antitussive }\end{array}$ & Aucubin & 3.0 & & & & & & & & & & & & & & $\begin{array}{l}\text { Park and Chang, 2004; } \\
\text { Tzeng et al., 2016; Li } \\
\text { et al., 2020. }\end{array}$ \\
\hline
\end{tabular}

All crude drugs are listed in the 17th edition of the Japanese Pharmacopeia (Pharmaceutical and Medical Device Regulatory Science Society of Japan, 2017). Class 1, crude drugs with analgesic and anti-inflammatory effects; Class 2, drugs with anti-stress effects; Class 3, drugs with blood flow-improving effects; Class 4, drugs that enhance the digestive function and improve physical strength; and Class 5, drugs that improve water metabolism, suppress swelling, and confer a diuretic effect. Traditional medicine (TM) is added to the terms used in the content of traditional Kampo medicine. Weights (g) indicate the amount of each crude drug to produce each Kampo formula, and the crude drugs marked with (*) and bold are the most active components of each medicine (Takayama, 2019). Except for GJG and YKS, the contents of crude drugs differ depending on the manufacturers, so some patterns were shown. One of the crude drugs marked with (\#) (Atractylodis rhizoma or Atractylodis lanceae rhizoa) is used. GJG, Goshajinkigan; EJT, Eppikajutsuto; KBG, Keishibukuryogan; GRS, Goreisan; YKS, Yokukansan; JTT, Juzentaihoto; KJT, Keishikajutsubuto; SKT, Saikokeishito. 
drowsiness, drug eruption, and myelosuppression, also cause dose reduction or discontinuation of administration. In such cases, the carbamazepine dosage may be reduced by concomitant use of Kampo formulae. Kampo formula treatment is a useful countermeasure against side effects caused by long-term carbamazepine use. Frequent treatments for trigeminal neuralgia include GRS (Kido et al., 2017), Saikokeshito (SKT) and KJT.

Glossopharyngeal neuralgia is paroxysmal pain induced by coughing, swallowing, mastication, conversation, and yawning. It occurs mainly in the back of the ear, behind the tongue, tonsils, and pharynx and just below the lower jaw angle. The incidence is reportedly $0.2 / 100,000$, making it a very rare disease. GRS is a common glossopharyngeal neuralgia treatment that it seems to confer anti-inflammatory effects and helps reduce edema around the nerve.

The reason GRS works for trigeminal and glossopharyngeal neuralgias is unclear. However, according to oriental medical theory, neuralgia is caused by the swelling of nerves. Therefore, GRS, which has a diuretic effect, is effective against these neuralgias. KJT would be better for cases with strong symptoms of coldness.

\section{Saikokeshito (Chai Hu Gui Zhi Tang)}

Saikokeshito was first described in Jin Gui Yao Lue (Zhang, 2020) and Shang Hang Lun (Zhang, 1999). SKT is usually given to patients with cold accompanied by gastrointestinal symptoms. Still, most crude drugs such as Glycyrrhizae radix, Paeoniae radix, Cinnamomi cortex, Scutellariae radix, and Bupleuri radix have analgesic and anti-inflammatory effects. SKT has been reported to exert analgesic activity in a rat trigeminal neuralgia model (Sunagawa et al., 2001). Some reports indicate the efficacy of SKT for epilepsy (Aimi et al., 1976). Therefore, SKT may have an anticonvulsant effect and may be effective for trigeminal neuralgia.

\section{ACTION MECHANISMS OF YOKUKANSAN FOR NEUROPATHIC PAIN}

Kampo medicines have a long history, and although their effectiveness has been empirically recognized, their mechanisms of action have not been completely clarified. However, in recent years, basic research on the Kampo formula has been actively conducted, and evidence based Kampo medicine treatments are also being carried out. For physicians who are trained under Western medicine, evidence-based drug selection is more familiar and easier to understand than narrative-based ones. In this section we will consider the mechanism through which Kampo formulae exert their analgesic effects, using YKS as an example.

YKS has been found clinically effective for diseases with chronic pain, including post-herpetic neuralgia, central poststroke pain, post-traumatic spinal cord injury pain, thalamic syndrome, complex regional pain syndrome (CRPS; Nakamura et al., 2009), trigeminal neuralgia (Yamaguchi, 2015; Takinami et al., 2017), phantom pain (Sugasawa, 2016), migraine (Akiyama and Hasegawa, 2019), and headache (Kimura et al., 2008). Mitsuhata et al. (2010) administered YKS to 121 patients with chronic pain who did not respond to conventional drug therapy or nerve block treatment and found it effective in 73 patients (60\%). They also found YKS to be effective in 25 of 47 chronic lumbar and inferior limb pain cases (53\%), 3 of 6 cervical or lumbar post-surgery syndrome cases (50\%), 13 of 20 postherpetic neuralgia cases (65\%), 6 of 8 herpes zoster neuralgia cases (75\%), 7 of 15 cervical spondylosis/cervical spondylotic radiculopathy cases (47\%), 2 of 4 perineal pain cases $(50 \%)$, and 6 of 6 CRPS cases (100\%). Considering that all of these entities are intractable painful diseases, the efficacy rate seems to be relatively high.

The analgesic effect of YKS has been proven in some animal models, including a chronic constriction injury (CCI) model (Suzuki et al., 2012; Suga et al., 2015), partial sciatic nerve ligation (PSL) model (Ebisawa et al., 2015), bone metastasis model (Nakao et al., 2019), and adjuvant arthritis model (Honda et al., 2013). Several factors are involved in the complex development and promotion of neuropathic pain. Increased reactivity of the dorsal horn of the spinal cord, i.e., central sensitization, is considered one cause of hyperalgesia and allodynia. Central sensitization includes the following: (1) enhancement of excitatory synaptic transmission, (2) attenuation of inhibitory synaptic transmission, (3) activation of glial cells, and (4) dysfunction of the descending pain modulatory system.

\section{Enhancement of Excitatory Synaptic Transmission and Yokukansan}

From the terminal of the primary afferent nerve C-fiber, neurotransmitters like glutamate and substance $\mathrm{P}$ act on each receptor in the dorsal horn of the spinal cord. Continuous or repetitive stimulation from the primary nerve promotes excitatory synaptic transmission by activating and phosphorylating the glutamate receptor, $N$-methyl-D-aspartate (NMDA) receptor.

YKS was observed to attenuate excessive glutamate release from presynaptic sites (Takeda et al., 2008). The removal of glutamate in the synaptic cleft is mainly carried out by the two glutamate transporters in astrocytes: glutamate transporter 1 (GLT- 1) and glutamate/aspartate transporter. YKS has been reported to promote the GLT-1-mediated uptake of glutamate using cultured astrocytes (Ueki et al., 2018). This action appears to be due to Glycyrrhizin and its metabolite, $18 \beta$-glycyrrhetinic acid, as well as a compound found in Glycyrrhizae radix (Kawakami et al., 2010). Furthermore, YKS has an antagonistic effect on the NMDA receptor. Isoliquiritigenin, a component of Glycyrrhizae radix, acts as the antagonist (Kawakami et al., 2011). Thus, YKS may suppress excessive neurotransmission mediated by glutamate. Suzuki et al. (2012) reported that YKS inhibited mechanical and cold allodynia in the rat CCI model and reduced the cerebrospinal fluid dialyzate level of glutamate increased by stimulation with a brush or acetone.

\section{Attenuation of Inhibitory Synaptic Transmission and Yokukansan}

The hypofunctions of GABAergic neurons, which are inhibitory interneurons in the spinal dorsal horn, occurred in rodents with chronic pain (Fu et al., 2017). YKS has been reported to reverse 
the reduction in pentobarbital-induced sleep durations in socially isolated mice (Egashira et al., 2011). It also exhibited anxiolytic effects (Kamei et al., 2009), which are thought to be mediated by $\mathrm{GABA}_{\mathrm{A}}$ receptors. Liao et al. (1995) reported that the water extract of Angelicae acutilobae radix binds to $\mathrm{GABA}_{\mathrm{A}}$ receptors in vitro. These findings suggest that YKS can be expected to exert an inhibitory effect on synaptic transmissions via the GABAergic neuron.

\section{Activation of Glial Cells and Yokukansan}

In animal models of schizophrenia (Furuya et al., 2013), multiple sclerosis (Nomura et al., 2017), and behavioral and psychological symptoms of dementia (Ikarashi et al., 2009), YKS suppresses glial cell (microglia and astrocytes) activity. The activation of these glial cells is associated with the development and persistence of neuropathic pain (Tsuda, 2018), so glial cells and their associated molecules became the targets of YKS treatment. Suga et al. (2015) reported that the administration of YKS inhibited the expression of activated astrocytes and astrogliosis in the CCI rat model. Ebisawa et al. (2015) reported that YKS inhibited the increased expression of interleukin- 6 mRNA in the dorsal horn of the spinal cord in the PSL mouse model, and the expression was confirmed in astrocytes and/or microglia, not in neurons. Furthermore, only the administration of Atratylodis Lanceae rhizoma exhibited the same effect. These studies suggest that YKS is effective against neuropathic pain, as evidenced by the regulation of microglial and astrocytic functions, which indicate the formula's potential mechanisms.

\section{Dysfunction of the Descending Pain Modulatory System and Yokukansan}

Descending neurons from the rostral ventromedial medulla mainly secrete serotonin. In contrast, neurons from the locus ceruleus secrete noradrenaline. Serotonin acts on $5-\mathrm{HT}_{1 \mathrm{~A}}$ and $5-\mathrm{HT}_{1 \mathrm{~B}}$ receptors, which are suppressive serotonin receptors in spinal dorsal horn neurons. Noradrenaline acts on $\alpha 2$ receptors, which suppress synaptic transmission. SNRI treats chronic pain with the expectation that this effect will be enhanced. Dysfunction of the descending pain modulatory system reportedly involves the development of chronic pain (Ossipov et al., 2014). YKS acts as an agonist of the 5- $\mathrm{HT}_{1 \mathrm{~A}}$ receptor; geissoschizine methyl ether, an alkaloid synthesized by the YKS component Uncariae uncis cum ramulus, is believed to play this role (Nishi et al., 2012; Yamaguchi et al., 2012). However, whether or not YKS improves the dysfunction of the descending pain modulatory system is unclear, so further studies are needed.

\section{Other Actions of Yokukansan}

The pre-administration of YKS attenuated the development of morphine antinociceptive tolerance, and suppression of glial cell activation may be one mechanism underlying this phenomenon (Takemoto et al., 2016; Katayama et al., 2018). A study that investigated orexin secretion found that orexin secretion was significantly increased in rats with morphine tolerance; however, YKS administration significantly suppressed it (Katayama et al., 2018). Orexin is a neuropeptide secreted from the hypothalamus.

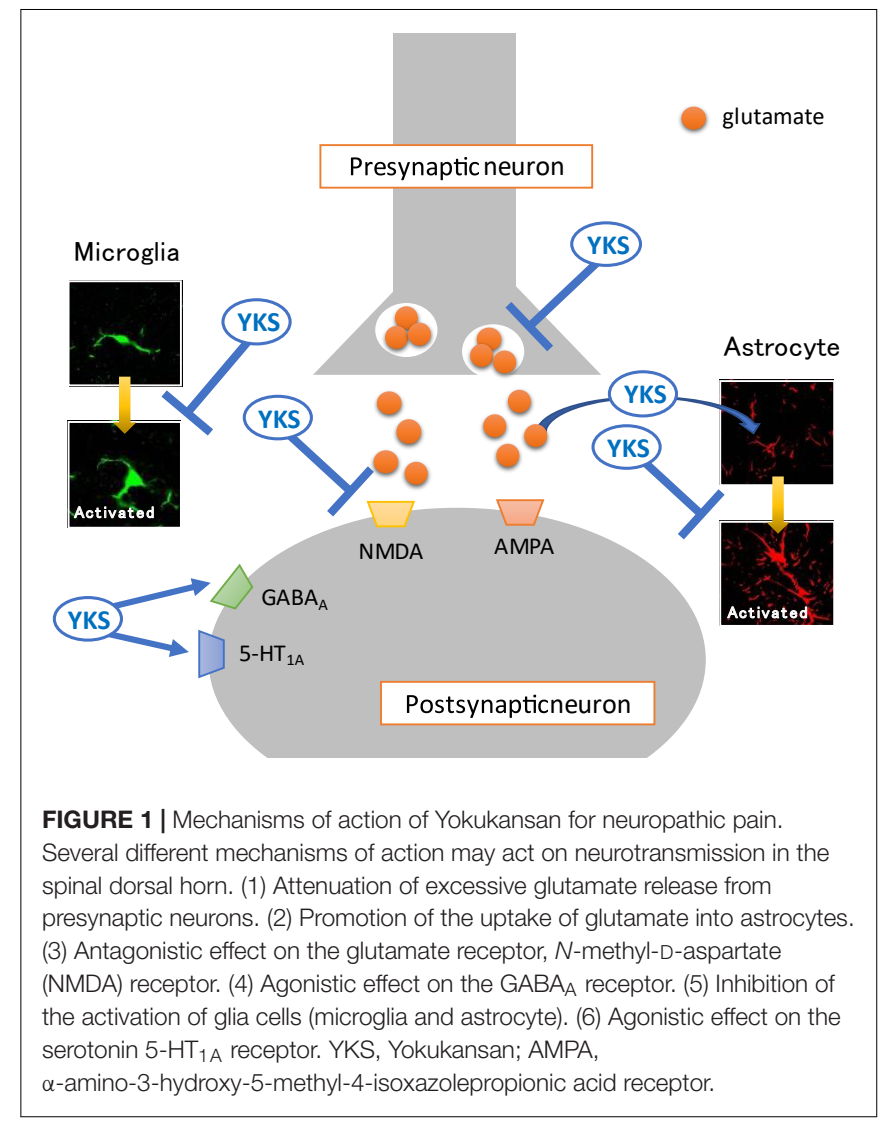

It has an analgesic effect (Yamamoto et al., 2003), but under pathological conditions of chronic pain, the excessive secretion of orexin may disrupt the pain modulatory system. The administration of an orexin receptor antagonist to rats with morphine tolerance, therefore suppressed the decrease in the pain threshold (Erami et al., 2012) and also exerted analgesic effects against acute and chronic pain (McDonald et al., 2016). We also found that YKS suppressed orexin secretion in a dose-dependent manner in healthy rats (Katahira et al., 2017). These findings suggest that the analgesic effect of YKS is partly involved in the inhibition of orexin secretion.

Oxytocin is also a neuropeptide secreted from the hypothalamus and has been reported to have a central-acting analgesic effect (Sun et al., 2018; González-Hernández et al., 2019). YKS administration also increased oxytocin secretion in rats (Kanada et al., 2018). The analgesic effect of YKS may be related to the secretagogue effect of oxytocin. Future studies should be conducted using pain model animals. Figure 1 summarizes the main actions of YKS.

\section{CONCLUSION}

The multiple ingredients that comprise Kampo formulae exert various beneficial effects. Although the individual pharmacological action of the components might be weak, the combination of these actions confers a holistic effect on 
intractable pain. This is an important point to consider in future pain treatment strategies. Multiple central sensitizations cause chronic pain; therefore, multi-component drugs, such as Kampo formulae, are more beneficial than seeking a strong analgesic effect with a single agent. In addition, identifying the active ingredients in the drugs used in traditional medicine can lead to the development of new drugs.

\section{REFERENCES}

Aimi, S., Saito, T., and Matsuda, T. (1976). The effect of Saiko-Keishito on the treatment of epilepsy, referring to the improvement of the electroencephalogram of them [in Japanese, English abstract]. J. Jpn. Soc. Orient. Med. 27, 99-116.

Akiyama, H., and Hasegawa, Y. (2019). Effectiveness of the traditional Japanese Kampo medicine Yokukansan for chronic migraine: A case report. Med 98:e17000. doi: 10.1097/MD.0000000000017000

Bethea, J. R., and Fischer, R. (2021). Role of Peripheral Immune Cells for Development and Recovery of Chronic Pain. Front. Immunol. 12:641588. doi: 10.3389/fimmu.2021.641588

Cascella, M., and Muzio, M. R. (2017). Potential application of the Kampo medicine goshajinkigan for prevention of chemotherapy-induced peripheral neuropathy. J. Integr. Med. 15, 77-87. doi: 10.1016/S2095-4964(17)60313-3

Chang, C. P., Chang, J. Y., Wang, F. Y., and Chang, J. G. (1995). The effect of Chinese medicinal herb Zingiberis rhizoma extract on cytokine secretion by human peripheral blood mononuclear cells. J. Ethnopharmacol. 48, 13-19. doi: 10.1016/0378-8741(95)01275-i

Cheng, Y., Zhang, Y., Xing, H., Qian, K., Zhao, L., and Chen, X. (2017). Comparative Pharmacokinetics and Bioavailability of Three Ephedrines in Rat after Oral Administration of Unprocessed and Honey-Fried Ephedra Extract by Response Surface Experimental Design. Evid. Based Complement. Alternat. Med. 2017:2802193. doi: 10.1155/2017/2802193

Choi, T. Y., Jun, J. H., Park, B., Lee, J. A., You, S., Jung, J., et al. (2016). Concept of blood stasis in Chinese medical textbooks: a systematic review. Eur. J. Integr. Med. 8, 158-164. doi: 10.1016/j.eujim.2015.09.137

Chrubasik, S., Pittler, M. H., and Roufogalis, B. D. (2005). Zingiberis rhizoma: a comprehensive review on the ginger effect and efficacy profiles. Phytomedicine 12, 684-701. doi: 10.1016/j.phymed.2004.07.009

Churihar, R., Solanki, P., Vyas, S., Hemant Tanwani, H., and Shubham Atal, S. (2016). Analgesic activity of cinnamaldehyde per se and it's interaction with diclofenac sodium and pentazocine in swiss albino mice. Int. J. Phamacog. 3, 97-102. doi: 10.13040/IJPSR.0975-8232.IJP.3(2).97-102

Cruccu, G., Gronseth, G., Alksne, J., Argoff, C., Brainin, M., Burchiel, K., et al. (2008). AAN-EFNS guidelines on trigeminal neuralgia management. Eur. J. Neurol. 15, 1013-1028. doi: 10.1111/j.1468-1331.2008.02185.x

de Caires, S., and Steenkamp, V. (2010). Use of Yokukansan (TJ-54) in the treatment of neurological disorders: a review. Phytother. Res. 24, 1265-1270. doi: $10.1002 /$ ptr.3146

Deng, J., Han, J., Chen, J., Zhang, Y., Huang, Q., Wang, Y., et al. (2021). Comparison of analgesic activities of aconitine in different mice pain models. PLoS One 16:e0249276. doi: 10.1371/journal.pone.0249276

Dong, Y., Feng, Z. L., Chen, H. B., Wang, F. S., and Lu, J. H. (2018). Corni Fructus: a review of chemical constituents and pharmacological activities. Chin. Med. 13, 1-20. doi: 10.1186/s13020-018-0191-Z

Ebisawa, S., Andoh, T., Shimada, Y., and Kuraishi, Y. (2015). Yokukansan improves mechanical allodynia through the regulation of interleukin-6 expression in the spinal cord in mice with neuropathic pain. Evid. Based Complement. Alternat. Med. 2015:870687. doi: 10.1155/2015/870687

Egashira, N., Nogami, A., Iwasaki, K., Ishibashi, A., Uchida, N., Takasaki, K., et al. (2011). Yokukansan enhances pentobarbital-induced sleep in socially isolated mice: possible involvement of GABA(A)-benzodiazepine receptor complex. J. Pharmacol. Sci. 116, 316-320. doi: 10.1254/jphs.11079SC

Endo, F., Oguchi, T., Ikeda, M., Sugimura, T., Shiga, Y., Yashi, M., et al. (2008). Prospective clinical study of keishibukuryogan on pain caused by varicocele. J. Trad. Med. 25, 52-54. doi: 10.11339/jtm.25.52

\section{AUTHOR CONTRIBUTIONS}

YT and MS participated in the conception and design. KY and MS wrote the draft. All authors retrieved and reviewed the literature and accepted responsibility for the entire content of this manuscript and approved its submission.

Erami, E., Azhdari-Zarmehri, H., Rahmani, A., Ghasemi-Dashkhasan, E., Semnanian, S., and Haghparast, A. (2012). Blockade of orexin receptor 1 attenuates the development of morphine tolerance and physical dependence in rats. Pharmacol. Biochem. Behav. 103, 212-219. doi: 10.1016/j.pbb.2012. 08.010

Fan, J., Liu, S., Ai, Z., Chen, Y., Wang, Y., Li, Y., et al. (2021). Fermented ginseng attenuates lipopolysaccharide-induced inflammatory responses by activating the TLR4/MAPK signaling pathway and remediating gut barrier. Food Funct. 12, 852-861. doi: 10.1039/d0fo02404j

Finnerup, N. B., Attal, N., Haroutounian, S., McNicol, E., Baron, R., Dworkin, R. H., et al. (2015). Pharmacotherapy for neuropathic pain in adults: a systematic review and meta-analysis. Lancet Neurol. 14, 162-173.

Fu, H., Li, F., Thomas, S., and Yang, Z. (2017). Hyperbaric oxygenation alleviates chronic constriction injury (CCI)-induced neuropathic pain and inhibits GABAergic neuron apoptosis in the spinal cord. Scand. J. Pain 17, 330-338. doi: 10.1016/j.sjpain.2017.08.014

Fujita, K., Yamamoto, T., Kamezaki, T., and Matsumura, A. (2010). Efficacy of keishibukuryogan, a traditional Japanese herbal medicine, in treating cold sensation and numbness after stroke: clinical improvement and skin temperature normalization in 22 stroke patients. Neurol. Med. Chir. 50, 1-6. doi: 10.2176/nmc.50.1

Furuya, M., Miyaoka, T., Tsumori, T., Liaury, K., Hashioka, S., Wake, R., et al. (2013). Yokukansan promotes hippocampal neurogenesis associated with the suppression of activated microglia in Gunn rat. J. Neuroinflamm. 10:145.

González-Hernández, A., Espinosa, De Los Monteros-Zuñiga, A. E., MartínezLorenzana, G., and Condés-Lara, M. (2019). Recurrent antinociception induced by intrathecal or peripheral oxytocin in a neuropathic pain rat model. Exp. Brain Res. 237, 2995-3010. doi: 10.1007/s00221-019-05651-7

Goto, F., Morimoto, N., Taiji, H., Tsutumi, T., and Ogawa, K. (2013). Treating pediatric psychogenic dizziness with a Japanese herbal medicine. Explore 9, 41-43. doi: 10.1016/j.explore.2012.10.005

Guo, J., Zhang, F., Gao, J., Guan, X., Liu, B., Wang, X., et al. (2020). Proteomicsbased screening of the target proteins associated with antidepressant-like effect and mechanism of Saikosaponin A. J. Cell Mol. Med. 24, 174-188. doi: 10.1111/ jcmm.14695

Hamaguchi, T., Yoshino, T., Horiba, Y., and Watanabe, K. (2017). Goshajinkigan for low back pain: an observational study. J. Altern. Complement. Med. 23, 208-213. doi: 10.1089/acm.2016.0276

Han, C. W., Kwun, M. J., Kim, K. H., Choi, J. Y., Oh, S. R., Ahn, K. S., et al. (2013). Ethanol extract of Alismatis Rhizoma reduces acute lung inflammation by suppressing NF-кB and activating Nrf2. J. Ethnopharmacol. 146, 402-410. doi: 10.1016/j.jep.2013.01.010

Hannibal, K. E., and Bishop, M. D. (2014). Chronic stress, cortisol dysfunction, and pain: A psychoneuroendocrine rationale for stress management in pain rehabilitation. Phys. Ther. 94, 1816-1825. doi: 10.2522/ptj.20130597

Hao, E., Pang, G., Du, Z., Lai, Y.-H., Chen, J.-R., Xie, J., et al. (2019). Peach Kernel Oil Downregulates Expression of Tissue Factor and Reduces Atherosclerosis in ApoE knockout Mice. Int. J. Mol. Sci. 20:405. doi: 10.3390/ijms200 20405

Hatano, R., Takano, F., Fushiya, S., Michimata, M., Tanaka, T., Kazama, I., et al. (2004). Water-soluble extracts from Angelica acutiloba Kitagawa enhance hematopoiesis by activating immature erythroid cells in mice with 5-fluorouracil-induced anemia. Exp. Hematol. 32, 918-924. doi: 10.1016/j. exphem.2004.07.003

He, X. Y., Wu, L. J., Wang, W. X., Xie, P. J., Chen, Y. H., and Wang, F. (2020). Amygdalin-A pharmacological and toxicological review. J. Ethnopharmacol. 254:112717. doi: $10.1016 /$ j.jep.2020.112717 
He, X., Wang, X., Fang, J., Chang, Y., Ning, N., Guo, H., et al. (2017). The genus Achyranthes: A review on traditional uses, phytochemistry, and pharmacological activities. J. Ethnopharmacol. 203, 260-278. doi: 10.1016/j.jep. 2017.03.035

Herzberg, U., Murtaugh, M., and Beitz, A. J. (1994). Chronic pain and immunity: mononeuropathy alters immune responses in rats. Pain 59, 219-225. doi: 10. 1016/0304-3959(94)90074-4

Hirai, A., Terano, T., Hamazaki, T., Sajiki, J., Saito, H., Tahara, K., et al. (1983). Studies on the mechanism of antiaggregatory effect of Moutan Cortex. Thromb. Res. 3, 29-40. doi: 10.1016/0049-3848(83)90005-1

Honda, Y., Sunagawa, M., Yoneyama, S., Ikemoto, H., Nakanishi, T., Iwanami, H., et al. (2013). Analgesic and anti-stress effects of Yokukansan in rats with adjuvant arthritis. Kampo Med. 64, 78-85. doi: 10.3937/kampomed.64.78

Hwang, J. M., Tseng, T. H., Hsieh, Y. S., Chou, F. P., Wang, C. J., and Chu, C. Y. (1996). Inhibitory effect of atractylon on tert-butyl hydroperoxide induced DNA damage and hepatic toxicity in rat hepatocytes. Arch. Toxicol. 70, 640-644. doi: $10.1007 / \mathrm{s} 002040050323$

Ikarashi, Y., Iizuka, S., Imamura, S., Yamaguchi, T., Sekiguchi, K., Kanno, H., et al. (2009). Effects of yokukansan, a traditional Japanese medicine, on memory disturbance and behavioral and psychological symptoms of dementia in thiamine-deficient rats. Biol. Pharm. Bull. 32, 1701-1709. doi: 10.1248/bpb. 32.1701

Irshad, Z., Hanif, M. A., Ayub, M. A., Hanif, A., and Afridi, H. I. (2020). "Jujube," in Medicinal Plants of South Asia, eds M. A. Hanif, H. Nawaz, M. M. Khan, and H. J. Byrne (Amsterdam: Elsevier), 451-463.

Ishikawa, S., Ishikawa, T., Tezuka, C., Asano, K., Sunagawa, M., and Hisamitsu, T. (2017). Efficacy of Juzentaihoto for Tumor Immunotherapy in B16 Melanoma Metastasis Model. Evid. Based Complement. Alternat. Med. 2017:6054706. doi: $10.1155 / 2017 / 6054706$

Ito, A., Munakata, K., Imazu, Y., and Watanabe, K. (2012). First nationwide attitude survey of Japanese physicians on the use of traditional Japanese medicine (kampo) in cancer treatment. Evid. Based Complement. Alternat. Med. 2012:957082. doi: 10.1155/2012/957082

Iwasaki, Y., Tanabe, M., Kobata, K., and Watanabe, T. (2008). TRPA1 agonistsallyl isothiocyanate and cinnamaldehyde-induce adrenaline secretion. Biosci. Biotechnol. Biochem. 72, 2608-2614. doi: 10.1271/bbb.80289

Jung, S. K., Choi, D. W., Kwon, D. A., Kim, M. J., Seong, K. S., and Shon, D. H. (2015). Oral administration of achyranthis radix extract prevents TMA-induced allergic contact dermatitis by regulating th2 cytokine and chemokine production in vivo. Molecules 20, 21584-21596. doi: 10.3390/ molecules201219788

Kai, X., and Ji, X. (2016). Bao ying cuo yao. Beijing: China Press of Traditional Chinese Medicine.

Kamei, J., Miyata, S., and Ohsawa, M. (2009). Involvement of the benzodiazepine system in the anxiolytic-like effect of Yokukansan (Yi-gan san). Prog. Neuropsychopharmacol. Biol. Psychiatry 33, 1431-1437. doi: 10.1016/j.pnpbp. 2009.07.023

Kamei, J., Saitoh, A., Asano, T., Nakamura, R., Ichiki, H., Iiduka, A., et al. (2005). Pharmacokinetic and pharmacodynamic profiles of the antitussive principles of Glycyrrhizae radix (licorice), a main component of the Kampo preparation Bakumondo-to (Mai-men-dong-tang). Eur. J. Pharmacol. 507, 163-168. doi: 10.1016/j.ejphar.2004.11.042

Kanada, Y., Katayama, A., Ikemoto, H., Takahashi, K., Tsukada, M., Nakamura, A., et al. (2018). Inhibitory effect of the Kampo medicinal formula Yokukansan on acute stress-induced defecation in rats. Neuropsychiatr. Dis. Treat. 14, 937-944. doi: 10.2147/NDT.S156795

Katahira, H., Sunagawa, M., Watanabe, D., Kanada, Y., Katayama, A., Yamauchi, R., et al. (2017). Antistress effects of Kampo medicine "Yokukansan" via regulation of orexin secretion. Neuropsychiatr. Dis. Treat. 13, 863-872. doi: 10.2147/NDT. S129418

Katayama, A., Kanada, Y., Tsukada, M., Akanuma, Y., Takemura, H., Ono, T., et al. (2018). Yokukansan (Kampo medicinal formula) prevents the development of morphine tolerance by inhibiting the secretion of orexin A. Integr. Med. Res. 7 , 141-148. doi: 10.1016/j.imr.2018.02.005

Kawakami, Z., Ikarashi, Y., and Kase, Y. (2010). Glycyrrhizin and its metabolite $18 \beta$-glycyrrhetinic acid in Glycyrrhiza, a constituent herb of yokukansan, ameliorate thiamine deficiency-induced dysfunction of glutamate transport in cultured rat cortical astrocytes. Eur. J. Pharmacol. 626, 154-158. doi: 10.1016/j. ejphar.2009.09.046

Kawakami, Z., Ikarashi, Y., and Kase, Y. (2011). Isoliquiritigenin is a novel NMDA receptor antagonist in Kampo medicine yokukansan. Cell. Mol. Neurobiol. 31, 1203-1212. doi: 10.1007/s10571-011-9722-1

Kido, H., Komasawa, N., Fujiwara, S., and Minami, T. (2017). Efficacy of go-rei-san for pain management in four patients with intractable trigeminal neuralgia [In Japanese, English Abstract]. Masui 66, 184-186.

Kim, S., Shin, S., Hyun, B., Kong, H., Han, S., Lee, A., et al. (2012). Immunomodulatory Effects of Dioscoreae Rhizome Against Inflammation through Suppressed Production of Cytokines Via Inhibition of the NF- $\kappa \mathrm{B}$ Pathway. Immune Netw. 12, 181-188. doi: 10.4110/in.2012.12.5.181

Kimura, Y., Shimizu, S., Tanaka, A., Suzuki, M., Kinebuchi, A., Inaki, K., et al. (2008). Efficacy of yokukansan-based prescriptions for the treatment of patients with headache [In Japanese, English Abstract]. Kampo Med. 59, 265-271. doi: 10.3937/kampomed.59.265

Kogure, T., Harada, N., Tatsumi, T., and Fujinaga, H. (2013). Persistent undifferentiated arthritis successfully treated with the Japanese herbal medicine “Eppikajutsuto". Eur. J. Integr. Med. 5, 184-188. doi: 10.1016/j.eujim.2012.11. 001

Koonrungsesomboon, N., Na-Bangchang, K., and Karbwang, J. (2014). Therapeutic potential and pharmacological activities of Atractylodes lancea (Thunb.) DC. Asian Pac. J. Trop. Med. 7, 421-428. doi: 10.1016/S1995-7645(14)60069-9

Kuchta, K. (2019). Traditional Japanese kampo medicine-history of ideas and practice; Part 1: from ancient shamanic practice to the medical academies of Edo. Trad. Kampo Med. 6, 49-56. doi: 10.1002/tkm2.1209

Kurihara, Y., Han, C., Harada, Y., and Kobayashi, H. (2018). General introduction to Kampo medicine - the nuts and bolts of Kampo -. Juntendo Med. J. 64, 258-263. doi: 10.14789/jmj.2018.64.JMJ18-R09

Lee, S. C., Wang, S. Y., Li, C. C., and Liu, C. T. (2018). Anti-inflammatory effect of cinnamaldehyde and linalool from the leaf essential oil of Cinnamomum osmophloeum Kanehira in endotoxin-induced mice. J. Food Drug Anal. 26, 211-220. doi: 10.1016/j.jfda.2017.03.006

Lee, S. M., Lee, Y. J., Yoon, J. J., Kang, D. G., and Lee, H. S. (2012). Effect of Poria cocos on hypertonic stress-induced water channel expression and apoptosis in renal collecting duct cells. J. Ethnopharmacol. 141, 368-376. doi: 10.1016/j.jep. 2012.02.048

Lee, W. S., Shin, J. S., Jang, D. S., and Lee, K. T. (2016). Cnidilide, an alkylphthalide isolated from the roots of Cnidium officinale, suppresses LPS-induced NO, PGE2, IL-1 $\beta$, IL- 6 and TNF- $\alpha$ production by AP-1 and NF- $\mathrm{B}$ inactivation in RAW 264.7 macrophages. Int. Immunopharmacol. 40, 146-155. doi: 10.1016/j. intimp.2016.08.021

Leong, P. K., Chen, J., and Ko, K. M. (2018). "Development of Chinese Herbal Health Products for the Prevention of Aging-Associated Diseases," in Natural Products and Drug Discovery, eds S. C. Mandal, V. Mandal, and T. Konishi (Amsterdam: Elsevier), 73-104. doi: 10.1016/B978-0-08-102081-4.00004-6

Li, C., Wen, R., Liu, W., Liu, Q., Yan, L. P., Wu, J. X., et al. (2020). Diuretic Effect and Metabolomics Analysis of Crude and Salt-Processed Plantaginis Semen. Front. Pharmacol. 11:563157. doi: 10.3389/fphar.2020.563157

Li, Y., Wu, P., Ning, Y., Yan, X., Zhu, T., Ma, C., et al. (2014). Sedative and hypnotic effect of freeze-dried paeoniflorin and Sini San freeze-dried powder in pentobarbital sodium-induced mice. J. Tradit. Chin. Med. 34, 184-187. doi: 10.1016/s0254-6272(14)60076-5

Liao, J. F., Jan, Y. M., Huang, S. Y., Wang, H. H., Yu, L. L., and Chen, C. F. (1995). Evaluation with receptor binding assay on the water extracts of ten CNS-active Chinese herbal drugs. Proc. Natl. Sci. Counc. Repub. China B 19, 151-158.

Lin, S., Nie, B., Yao, G., Yang, H., Ye, R., and Yuan, Z. (2019). Pinellia ternata (Thunb.) Makino Preparation promotes sleep by increasing REM sleep. Nat. Prod. Res. 33, 3326-3329. doi: 10.1080/14786419.2018.1474466

Liu, K., Han, S., Gao, W., Tang, Y., Han, X., Liu, Z., et al. (2021). Changes of Mineralogical Properties and Biological Activities of Gypsum and Its Calcined Products with Different Phase Structures. Evid. Based Complement. Alternat. Med. 2021:6676797. doi: 10.1155/2021/6676797

Loh, Y. C., Ch'ng, Y. S., Tan, C. S., Ahmad, M., Asmawi, M. Z., and Yam, M. F. (2017). Mechanisms of action of Uncaria rhynchophylla ethanolic extract for its vasodilatory effects. J. Med. Food 20, 895-911. doi: 10.1089/jmf.2016.3804 
Lu, J., Tian, J., Zhou, L., Meng, L., Chen, S., Ma, C., et al. (2021). Phytochemistry and Biological Activities of Poria. J. Chem. 2021:6659775. doi: 10.1155/2021/ 6659775

Luo, C., Zhang, Y., Chi, L., Li, L., and Chen, K. (2009). Protective effect and mechanism of ecdysterone on injury of focal cerebral infarct in rats. Medical J. Natl. Defend. Forces Southwest China 19, 176-178.

Makino, B., Kobayashi, M., Kimura, K., Ishimatsu, M., Sakakibara, I., Higuchi, M., et al. (2002). Local variation in the content of angiotensin II and arginine vasopressin receptor antagonistic terpenoids in the rhizomes of Alisma orientale. Planta Med. 68, 226-231. doi: 10.1055/s-2002-23129

Matsubara, Y., Okuda, H., Harada, K. H., Youssefian, S., and Koizumi, A. (2021). Mechanical allodynia triggered by cold exposure in mice with the Scn11a p.R222S mutation: a novel model of drug therapy for neuropathic pain related to NaV1.9. Naunyn Schmiedeberg's Arch. Pharmacol. 394, 299-306. doi: 10.1007/ s00210-020-01978-z

McDonald, T., Liang, H. A., Sanoja, R., Gotter, A. L., Kuduk, S. D., Coleman, P. J., et al. (2016). Pharmacological evaluation of orexin receptor antagonists in preclinical animal models of pain. J. Neurogenet. 30, 32-41. doi: 10.3109/ 01677063.2016.1171862

Mitsuhata, H., Nakamura, Y., Kawagoe, I., Tajima, K., Kanai, M., Konishi, R., et al. (2010). Efficacy of yokukansan against neuropathic pain: clinical reports and the animal study [In Japanese, English Abstract]. Pain Kampo Med. 20, 13-19.

Miyagoshi, M., Amagaya, S., and Ogihara, Y. (1986). Antitussive effects of L-ephedrine, amygdalin, and makyokansekito (Chinese traditional medicine) using a cough model induced by sulfur dioxide gas in mice. Planta Med. 52, 275-278. doi: 10.1055/s-2007-969151

Moschik, E. C., Mercado, C., Yoshino, T., Matsuura, K., and Watanabe, K. (2012). Usage and attitudes of physicians in Japan concerning traditional Japanese medicine (kampo medicine): a descriptive evaluation of a representative questionnaire-based survey. Evid. Based Complement. Alternat. Med. 2012:139818. doi: 10.1155/2012/139818

Murakami, K., Horie, I., Hara-Chikuma, M., Shimizu, T., Matsumoto, C., and Isohama, Y. (2021). Goreisan regulates AQP3 expression and improves diarrhea. Tradit. Kampo Med. 8, 91-99. doi: 10.1002/tkm2.1276

Nakamura, Y., Tajima, K., Kawagoe, I., Kanai, M., and Mitsuhata, H. (2009). Efficacy of traditional herbal medicine, Yokukansan on patients with neuropathic pain [In Japanese, English Abstract]. Masui 58, 1248-1255.

Nakanishi, M., Arimitsu, J., Kageyama, M., Otsuka, S., Inoue, T., Nishida, S., et al. (2012). Efficacy of traditional Japanese herbal medicinesKeishikajutsubuto (TJ-18) and Bushi-matsu (TJ-3022) -against post-herpetic neuralgia aggravated by self-reported cold stimulation: a case series. J. Altern. Complement. Med. 18, 686-692. doi: 10.1089/acm.2010.0745

Nakao, K., Fujiwara, A., Komasawa, N., Jin, D., Kitano, M., Matsunami, S., et al. (2019). Yokukansan alleviates cancer pain by suppressing matrix metalloproteinase-9 in a mouse bone metastasis model. Evid. Based Complement. Alternat. Med. 2019:3513064. doi: 10.1155/2019/2956920

Ningsih, F. N., Okuyama, T., To, S., Nishidono, Y., Okumura, T., Tanaka, K., et al. (2020). Comparative Analysis of Anti-inflammatory Activity of the Constituents of the Rhizome of Cnidium officinale Using Rat Hepatocytes. Biol. Pharm. Bull. 43, 1867-1875. doi: 10.1248/bpb.b20-00416

Nishi, A., Yamaguchi, T., Sekiguchi, K., Imamura, S., Tabuchi, M., Kanno, H., et al. (2012). Geissoschizine methyl ether, an alkaloid in Uncaria hook, is a potent serotonin1A receptor agonist and candidate for amelioration of aggressiveness and sociality by yokukansan. Neuroscience 207, 124-136. doi: 10.1016/j.neuroscience.2012.01.037

Nishioka, M., Shimada, M., Kurita, N., Iwata, T., Morimoto, S., Yoshikawa, K., et al. (2011). The Kampo medicine, Goshajinkigan, prevents neuropathy in patients treated by FOLFOX regimen. Int. J. Clin. Oncol. 16, 322-327. doi: 10.1007/s10147-010-0183-1

Nomura, T., Bando, Y., You, H., Tanaka, T., and Yoshida, S. (2017). Yokukansan reduces cuprizone-induced demyelination in the corpus callosum through antiinflammatory effects on microglia. Neurochem. Res. 42, 3525-3536. doi: 10. 1007/s11064-017-2400-z

Nozaki, K., Goto, H., Nakagawa, T., Hikiami, H., Koizumi, K., Shibahara, N., et al. (2007). Effects of keishibukuryogan on vascular function in adjuvantinduced arthritis rats. Biol. Pharm. Bull. 30, 1042-1047. doi: 10.1248/bpb.30. 1042
Nukaya, H., Yamashiro, H., Fukazawa, H., Ishida, H., and Tsuji, K. (1996). Isolation of inhibitors of TPA-induced mouse ear edema from Hoelen, Poria cocos. Chem. Pharm. Bull. 44, 847-849. doi: 10.1248/cpb.44.847

Ogawa-Ochiai, K., Katagiri, T., Sato, Y., Shirai, A., Ishiyama, K., Takami, A., et al. (2021). Natural killer cell function changes by the Japanese Kampo Medicine juzentaihoto in General fatigue patients. Adv. Integr. Med. 8, 33-43. doi: 10. 1016/j.aimed.2019.12.003

Ossipov, M. H., Morimura, K., and Porreca, F. (2014). Descending pain modulation and chronification of pain. Curr. Opin. Support. Palliat. Care 8, 143-151. doi: 10.1097/SPC.0000000000000055

Park, K. S., and Chang, I. M. (2004). Anti-inflammatory activity of aucubin by inhibition of tumor necrosis factor- $\alpha$ production in RAW 264.7 cells. Planta Med. 70, 778-779. doi: 10.1055/s-2004-827211

Peng, W. H., Hsieh, M. T., Lee, Y. S., Lin, Y. C., and Liao, J. (2000). Anxiolytic effect of seed of Ziziphus jujuba in mouse models of anxiety. J. Ethnopharmacol. 72, 435-441. doi: 10.1016/s0378-8741(00)00255-5

Pengsuparp, T., Indra, B., Nakagawasai, O., Tadano, T., Mimaki, Y., Sashida, Y., et al. (2001). Pharmacological studies of geissoschizine methyl ether, isolated from Uncaria sinensis Oliv., in the central nervous system. Eur. J. Pharmacol. 425, 211-218. doi: 10.1016/s0014-2999(01)01195-5

Pharmaceutical and Medical Device Regulatory Science Society of Japan (2017). Japanese pharmacopoeia seventeenth edition (JP XVII) English version. Tokyo: Yakuji Nippo.

Ping, T., Min, H., Ji, H., and Bian, J. (2017). Taiping Huimin Heji Ju Fang. Beijin: People's Health Publisher.

Qiao, Y. L., Zhou, J. J., Liang, J. H., Deng, X. P., Zhang, Z. J., Huang, H. L., et al. (2021). Uncaria rhynchophylla ameliorates unpredictable chronic mild stressinduced depression in mice via activating 5-HT1A receptor: Insights from transcriptomics. Phytomedicine 81:153436. doi: 10.1016/j.phymed.2020.153436

Qiu, L. Z., Zhou, W., Yue, L. X., Wang, Y. H., Hao, F. R., Li, P. Y., et al. (2021). Repeated Aconitine Treatment Induced the Remodeling of Mitochondrial Function via AMPK-OPA1-ATP5A1 Pathway. Front. Pharmacol. 12:646121. doi: 10.3389/fphar.2021.646121

Qu, Q., Yang, F., Zhao, C., Liu, X., Yang, P., Li, Z., et al. (2021). Effects of fermented ginseng on the gut microbiota and immunity of rats with antibiotic-associated diarrhea. J. Ethnopharmacol. 267:113594. doi: 10.1016/j.jep.2020.113594

Saiki, I., Yokoyama, S., and Hayakawa, Y. (2017). Effect of juzentaihoto/Shi-QuanDa-Bu-Tang on malignant progression and metastasis of tumor cells. World J. Trad. Chin. Med. 3, 26-45. doi: 10.1248/bpb.23.677

Shi, K., Qu, L., Lin, X., Xie, Y., Tu, J., Liu, X., et al. (2019). Deep-Fried Atractylodis Rhizoma Protects against Spleen Deficiency-Induced Diarrhea through Regulating Intestinal Inflammatory Response and Gut Microbiota. Int. J. Mol. Sci. 21:124. doi: 10.3390/ijms21010124

Shimizu, M., Matsuzawa, T., Suzuki, S., Yoshizaki, M., and Morita, N. (1991). Evaluation of Angelicae Radix (Touki) by the inhibitory effect on platelet aggregation. Chem. Pharm. Bull. 39, 2046-2048. doi: 10.1248/cpb.39.2046

Shimizu, T., Shibuya, N., Narukawa, Y., Oshima, N., Hada, N., and Kiuchi, F. (2018). Synergistic effect of baicalein, wogonin and oroxylin A mixture: multistep inhibition of the NF- $\kappa$ B signalling pathway contributes to an antiinflammatory effect of Scutellaria root flavonoids. J. Nat. Med. 72, 181-191. doi: 10.1007/s11418-017-1129-y

Shin, J. S., Im, H. T., and Lee, K. T. (2019). Saikosaponin B2 Suppresses Inflammatory Responses Through IKK/I $\mathrm{B} \alpha / \mathrm{NF}-\kappa \mathrm{B}$ Signaling Inactivation in LPS-Induced RAW 264.7 Macrophages. Inflammation 42, 342-353. doi: 10. 1007/s10753-018-0898-0

Shinkai, T., Masumoto, K., Chiba, F., and Tanaka, N. (2017). A large retroperitoneal lymphatic malformation successfully treated with traditional Japanese Kampo medicine in combination with surgery. Surg. Case Rep. 3, 1-4. doi: 10.1186/ s40792-017-0358-3

Suga, H., Sunagawa, M., Ikemoto, H., Nakanishi, T., Fujiwara, A., and Okada, M. (2015). The analgesic and anti-stress effects of a Kampo medicine (Yokukansan) in rats with chronic constriction injury-a comparative study with kamishoyosan. J. Integr. Ther. 2:5. doi: 10.13188/2378-1343.1000009

Sugasawa, Y. (2016). Effect of yokukansan, Japanese herbal medicine, on phantomlimb pain. Middle East J. Anaesthesiol. 23, 499-500.

Sumitani, M., Sakai, T., Matsuda, Y., Abe, H., Yamaguchi, S., Hosokawa, T., et al. (2018). Executive summary of the clinical guidelines of pharmacotherapy for 
neuropathic pain: by the Japanese Society of Pain Clinicians. J. Anesth. 32, 463-478. doi: 10.1007/s00540-018-2501-0

Sun, W., Zhou, Q., Ba, X., Feng, X., Hu, X., Cheng, X., et al. (2018). Oxytocin relieves neuropathic pain through GABA release and presynaptic TRPV1 inhibition in spinal cord. Front. Mol. Neurosci. 11:248. doi: 10.3389/fnmol.2018. 00248

Sun, Y., and Yasukawa, K. (2008). New anti-inflammatory ergostane-type ecdysteroids from the sclerotium of Polyporus umbellatus. Bioorg. Med. Chem. Lett. 18, 3417-3420. doi: 10.1016/j.bmcl.2008.04.008

Sunagawa, M., Okada, M., Guo, S. Y., and Hisamitsu, T. (2000). Splenic natural killer cell activity is suppressed by ligation of unilateral mental nerve in rats [In Japanese, English abstract]. Masui Jap. J. Anesthesiol. 49, 250-254.

Sunagawa, M., Okada, M., Guo, S. Y., and Hisamitsu, T. (2001). Effectiveness of Saiko-Keishi-To (TJ-10, a Kampo herbal medicine) for trigeminal neuralgia in rats [In Japanese, English abstract]. Masui Jap. J. Anesthesiol. 50, 486-490.

Suzuki, Y., Mitsuhata, H., Yuzurihara, M., and Kase, Y. (2012). Antiallodynic effect of herbal medicine yokukansan on peripheral neuropathy in rats with chronic constriction injury. Evid. Based Complement. Alternat. Med. 2012:953459. doi: $10.1155 / 2012 / 953459$

Takaku, S., Shimizu, M., and Takahashi, H. (2020). Japanese Kampo Medicine Juzentaihoto Enhances Antitumor Immunity in CD1d-/Mice Lacking NKT Cells. Integr. Cancer Ther. 19:1534735419900798. doi: 10.1177/1534735419900798

Takayama, K. (2019). Kampo Joyoshohou Kaisetsu, edition 2nd Edn. Chiba: Toyo Gakujutsu Shuppansha.

Takayama, S., Arita, R., Kikuchi, A., Ohsawa, M., Kaneko, S., and Ishii, T. (2018). Clinical practice guidelines and evidence for the efficacy of traditional Japanese herbal medicine (Kampo) in treating geriatric patients. Front. Nutr. 5:66. doi: 10.3389/fnut.2018.00066

Takeda, A., Itoh, H., Tamano, H., Yuzurihara, M., and Oku, N. (2008). Suppressive effect of Yokukansan on excessive release of glutamate and aspartate in the hippocampus of zinc-deficient rats. Nutr. Neurosci. 11, 41-46. doi: 10.1179/ 147683008 X301414

Takemoto, M., Sunagawa, M., Okada, M., Ikemoto, H., Suga, H., Katayama, A., et al. (2016). Yokukansan, a Kampo medicine, prevents the development of morphine tolerance through the inhibition of spinal glial cell activation in rats. Integr. Med. Res. 5, 41-47. doi: 10.1016/j.imr.2015.12.003

Takinami, Y., Mita, K., Nagai, A., Yamakawa, J., and Ohara, H. (2017). A case of trigeminal neuralgia successfully treated with yokukansan [in Japanese, English abstract]. Kampo Med. 68, 358-361. doi: 10.3937/kampomed.68.358

The Editing Committee for the Dictionary of Kampo Medicine, the Japan Society for Oriental Medicine (2020). The Dictionary of Kampo Medicine-Basic terms-. Kyoto: Medical Yukon.

Tomita, T., Hirayama, A., Matsui, H., and Aoyagi, K. (2017). Effect of keishibukuryogan, a Japanese traditional Kampo prescription, on improvement of microcirculation and Oketsu and induction of endothelial nitric oxide: A live imaging study. Evid. Based Complement. Alternat. Med. 2017:3620130. doi: $10.1155 / 2017 / 3620130$

Tsuda, M. (2018). Modulation of pain and itch by spinal glia. Neurosci. Bull. 34, 178-185. doi: 10.1007/s12264-017-0129-y

Tzeng, T. F., Liu, W. Y., Liou, S. S., Hong, T. Y., and Liu, I. M. (2016). Antioxidantrich extract from plantaginis semen ameliorates diabetic retinal injury in a streptozotocin-induced diabetic rat model. Nutrients 8:572. doi: 10.3390/ nu8090572

Ueki, T., Kawakami, Z., Kanno, H., Omiya, Y., Mizoguchi, K., and Yamamoto, M. (2018). Yokukansan, a traditional Japanese medicine, enhances the glutamate transporter GLT-1 function in cultured rat cortical astrocytes. Evid. Based Complement. Alternat. Med. 2018:6804017. doi: 10.1155/2018/68 04017

Wada, S., Inoguchi, H., Hirayama, T., Matsuoka, Y. J., Uchitomi, Y., Ochiai, H., et al. (2017). Yokukansan for the treatment of preoperative anxiety and postoperative delirium in colorectal cancer patients: a retrospective study. Jpn. J. Clin. Oncol. 47, 844-848. doi: 10.1093/jjco/hyx080

Wang, H. L., Li, Y. X., Niu, Y. T., Zheng, J., Wu, J., Shi, G. J., et al. (2015). Observing Anti-inflammatory and Anti-nociceptive Activities of Glycyrrhizin Through Regulating COX-2 and Pro-inflammatory Cytokines Expressions in Mice. Inflammation 38, 2269-2278. doi: 10.1007/s10753-015-0212-3
Wang, L., Jing, N., Liu, X., Jiang, G., and Liu, Z. (2020). Nurturing and modulating gut microbiota with jujube powder to enhance anti-PD-L1 efficiency against murine colon cancer. J. Funct. Foods 64:103647. doi: 10.1016/j.jff.2019. 103647

Wei, H., Ding, L., Wang, X., Yan, Q., Jiang, C., Hu, C., et al. (2021). Astragalus root extract improved average daily gain, immunity, antioxidant status and ruminal microbiota of early weaned yak calves. J. Sci. Food Agric. 101, 82-90. doi: 10.1002/jsfa.10617

Wu, C., Shan, J., Feng, J., Wang, J., Qin, C., Nie, G., et al. (2019). Effects of dietary Radix Rehmanniae Preparata polysaccharides on the growth performance, immune response and disease resistance of Luciobarbus capito. Fish Shellfish Immunol. 89, 641-646. doi: 10.1016/j.fsi.2019.04.027

Wu, Z., Kong, X., Zhang, T., Ye, J., Fang, Z., and Yang, X. (2014). Pseudoephedrine/ephedrine shows potent anti-inflammatory activity against TNF- $\alpha$-mediated acute liver failure induced by lipopolysaccharide/Dgalactosamine. Eur. J. Pharmacol. 724, 112-121. doi: 10.1016/j.ejphar.2013.11. 032

Xin, Q., Yuan, R., Shi, W., Zhu, Z., Wang, Y., and Cong, W. (2019). A review for the anti-inflammatory effects of paeoniflorin in inflammatory disorders. Life Sci. 237:116925. doi: 10.1016/j.lfs.2019.116925

Xu, Y., Yu, Y., Wang, Q., Li, W., Zhang, S., Liao, X., et al. (2021). Active components of Bupleurum chinense and Angelica biserrata showed analgesic effects in formalin induced pain by acting on Nav1.7. J. Ethnopharmacol. 269:113736. doi: 10.1016/j.jep.2020.113736

Yamaguchi, K. (2015). Traditional Japanese herbal medicines for treatment of odontopathy. Front. Pharmacol. 6:176. doi: 10.3389/fphar.2015.00176

Yamaguchi, T., Tsujimatsu, A., Kumamoto, H., Izumi, T., Ohmura, Y., Yoshida, T., et al. (2012). Anxiolytic effects of yokukansan, a traditional Japanese medicine, via serotonin $5-\mathrm{HT}_{1 A}$ receptors on anxiety-related behaviors in rats experienced aversive stress. J. Ethnopharmacol. 143, 533-539. doi: 10.1016/j.jep.2012. 07.007

Yamahara, J., Matsuda, H., Huang, Q., Li, Y. U. H. A. O., and Fujimura, H. (1990). Intestinal motility enhancing effect of Atractylodes lancea rhizome. J. Ethnopharmacol. 29, 341-344. doi: 10.1016/0378-8741(90)90044-t

Yamakawa, J., Moriya, J., and Kobayashi, J. (2016). Fatigue and Kampo (Japanese herbal) medicines: Hochuekkito and juzentaihoto. Methods Pharmacol. Toxicol. 2016, 97-111. doi: 10.3389/fphar.2020.00917

Yamamoto, T., Saito, O., Shono, K., Aoe, T., and Chiba, T. (2003). Anti-mechanical allodynic effect of intrathecal and intracerebroventricular injection of orexin-A in the rat neuropathic pain model. Neurosci. Lett. 347, 183-186. doi: 10.1016/ s0304-3940(03)00716-X

Yan, Y. H., and Liu, Y. J. Z. (2012). Yan Shi Ji Sheng Fang (TCM clinical Intangible Cultural Heritage Classic Reader), 1st Edn. Tianjin: Chinese Medical Science and Technology Press.

Yano, Y., Yano, H., Takahashi, H., Yoshimoto, K., Tsuda, S., Fujiyama, K., et al. (2017). Goreisan Inhibits Upregulation of Aquaporin 4 and Formation of Cerebral Edema in the Rat Model of Juvenile Hypoxic-Ischemic Encephalopathy. Evid. Based. Complement. Alternat. Med. 2017:3209219. doi: $10.1155 / 2017 / 3209219$

Yin, D., Liu, Y. Y., Wang, T. X., Hu, Z. Z., Qu, W. M., Chen, J. F., et al. (2016). Paeoniflorin exerts analgesic and hypnotic effects via adenosine A1 receptors in a mouse neuropathic pain model. Psychopharmacology 233, 281-293. doi: 10.1007/s00213-015-4108-6

Yoshikawa, M., Yamaguchi, S., Kunimi, K., Matsuda, H., Okuno, Y., Yamahara, J., et al. (1994). Stomachic principles in ginger. III. An anti-ulcer principle, 6gingesulfonic acid, and three monoacyldigalactosylglycerols, gingerglycolipids A, B, and C, from Zingiberis Rhizoma originating in Taiwan. Chem. Pharm. Bull. 42, 1226-1230. doi: 10.1248/cpb.42.1226

Yoshimasu, T. (1181). Hoki. Available online at: https://rmda.kulib.kyoto-u.ac.jp/ item/rb00000733 (accessed August 16, 2021).

Yu, C., Xiong, Y., Chen, D., Li, Y., Xu, B., Lin, Y., et al. (2017). Ameliorative effects of atractylodin on intestinal inflammation and co-occurring dysmotility in both constipation and diarrhea prominent rats. Kor. J. Physiol. Pharmacol. 21, 1-9. doi: 10.4196/kjpp.2017.21.1.1

Yu, H. Y., Wang, S. J., Teng, J. L., Ji, X. M., Wu, Z. C., Ma, Q. C., et al. (2012). Effects of Radix aconiti lateralis preparata and Rhizoma zingiberis on energy metabolism and expression of the genes related to metabolism in rats. Chin. J. Integr. Med. 18, 23-29. doi: 10.1007/s11655-012-0964-7 
Zhang, G., Zeng, X., Han, L., Wei, J. A., and Huang, H. (2010). Diuretic activity and kidney medulla $\mathrm{AQP}_{1}, \mathrm{AQP}_{2}, \mathrm{AQP}_{3}, \mathrm{~V}_{2} \mathrm{R}$ expression of the aqueous extract of sclerotia of Polyporus umbellatus FRIES in normal rats. J. Ethnopharmacol. 128, 433-437. doi: 10.1016/j.jep.2010.01.032

Zhang, S., Tang, X., Tian, J., Li, C., Zhang, G., Jiang, W., et al. (2011). Cardioprotective effect of sulphonated formononetin on acute myocardial infarction in rats. Basic Clin. Pharmacol. Toxicol. 108, 390-395. doi: 10.1111/ j.1742-7843.2011.00676.x

Zhang, W. J., Zhao, Z. Y., Chang, L. K., Cao, Y., Wang, S., Kang, C. Z., et al. (2021). Atractylodis Rhizoma: A review of its traditional uses, phytochemistry, pharmacology, toxicology and quality control. J. Ethnopharmacol. 266:113415. doi: 10.1016/j.jep.2020.113415

Zhang, Y., Qiu, Z., Qiu, Y., Su, T., Qu, P., and Jia, A. (2019). Functional Regulation of Ginsenosides on Myeloid Immunosuppressive Cells in the Tumor Microenvironment. Integr. Cancer. Ther. 18:1534735419886655. doi: 10.1177/ 1534735419886655

Zhang, Z. (1999). Shang Han Lun: On Cold Damage, Translation \& Commentaries. Taos, NM: Paradigm Publications.

Zhang, Z. (2020). Essentials from the Golden Cabinet: Translation and Annotation of Jin Gui Yao Lue. Singapore: World Scientific.
Conflict of Interest: MS received a research grant from Tsumura \& Co. (Tokyo, Japan).

The remaining authors declare that the research was conducted in the absence of any commercial or financial relationships that could be construed as a potential conflict of interest.

Publisher's Note: All claims expressed in this article are solely those of the authors and do not necessarily represent those of their affiliated organizations, or those of the publisher, the editors and the reviewers. Any product that may be evaluated in this article, or claim that may be made by its manufacturer, is not guaranteed or endorsed by the publisher.

Copyright (c) 2021 Sunagawa, Takayama, Kato, Tanaka, Fukuoka, Okumo, Tsukada and Yamaguchi. This is an open-access article distributed under the terms of the Creative Commons Attribution License (CC BY). The use, distribution or reproduction in other forums is permitted, provided the original author(s) and the copyright owner(s) are credited and that the original publication in this journal is cited, in accordance with accepted academic practice. No use, distribution or reproduction is permitted which does not comply with these terms. 